\section{THE GLACIAL DRIFTS OF NORTH LONDON}

THE landscape memorials of the great glacial period 1 in Britain have hitherto been chiefly looked for by the tourist in the northern and mountainous districts of our island. The vast and wide-spreading products of the same epoch which lie in the lower and more southerly districts of England, as far as the Valley of the Thames, have had to wait longer for their due recognition. In the interval, the Londoner addicted to geologising has been fain to go to Snowdonia, Borrodaile, and the Highlands of Scotland-to the region of perched blocks and terminal moraines-for memorials of the Ice Age within our own coasts. Nor is it to be wondered at that the districts in which glacial action on a grand and cosmical scale was first detected in Iritain, and which still afford the more obvious monuments of the glacial period, should so long have monopolised attention. But the time scems now to have come for the drifts of the southern regions to take their proper place in the gallery of glacial phenomena.

So recently have these drifts changed their character in the ejes of geologists that it may be worth while to summarise their history, and indicate the conclusions which have now been arrived at with regard to them as well as one or two important moot points which will perhaps remain doubtful for some time to come.

It seems only yesterday that the glacial drifts of the

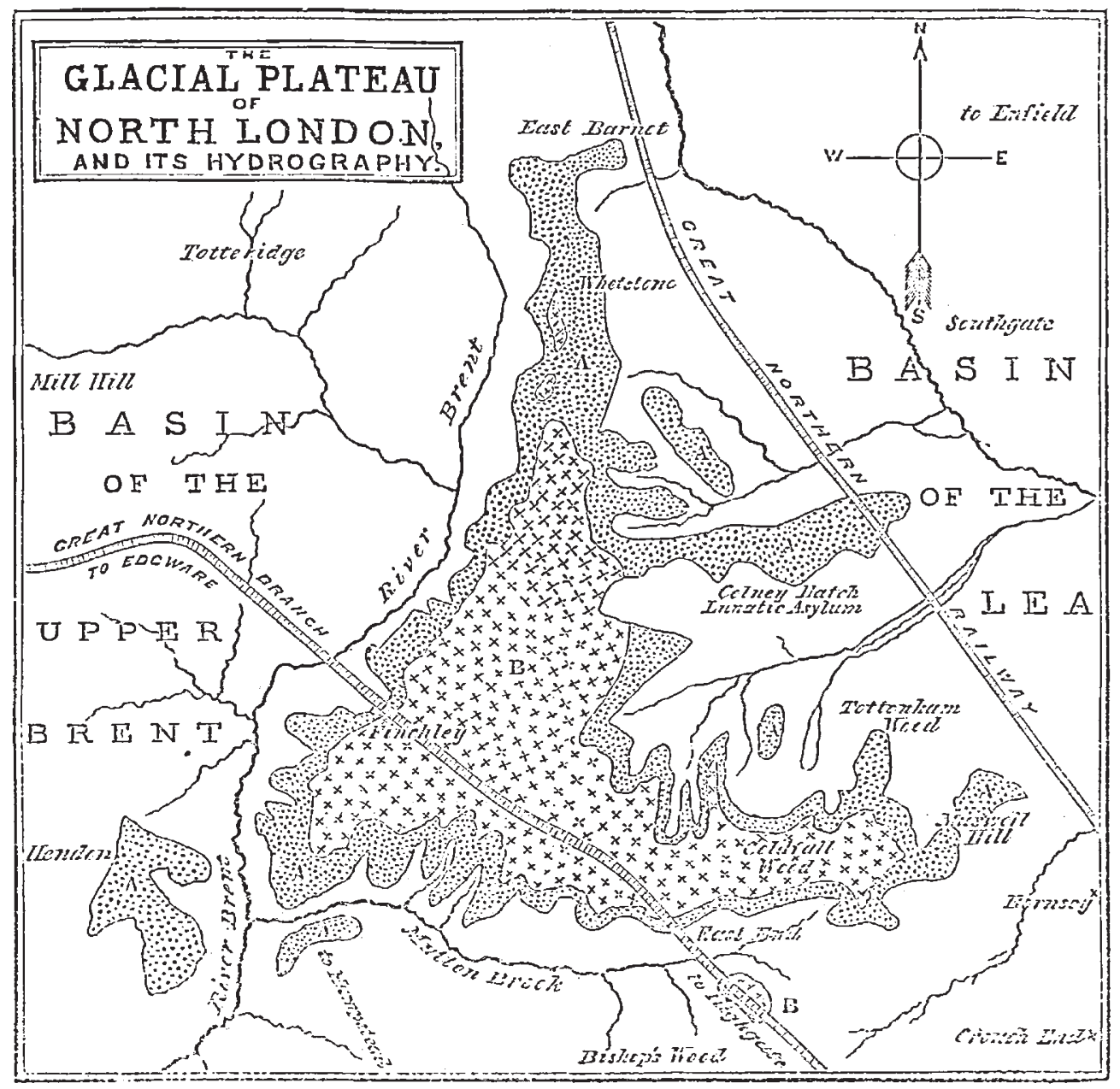

Fig. x.-A, Glacial Sabdšand Gravels, B, Glucial Clay. Unshaded Parts-London Clay.

lower and southern districts of England were looked upon as a mere congeries of rubbish heaps and "diluvium"chaotic and unintelligible relics of some mysterious and partly hypothetical period. Now, however, these deposits are no longer slighted by geologists. In the hands of one or two earnest workers-notably Mr. Searles V. Wood, jun.-the glacial clays, and sands, and gravels of England are rising into the dignity of a system. The North London glacial drifts may be taken as typical in most respects of the great and wide-spreading deposits which are found in the inland counties most remote from the homes of the old British glaciers.

The Finchley and Muswell Hill drift lying on the north- ern heights of London overlooking the Thames Valley occupies a position of great geological interest and significance. Muswell Hill figures in the very early annals of the beds which are known to be of glacial origin. In the year 1835 , Mr. N. T. Wetherell, of Highgate, made the discovery which has given such repute to the spot. In Coldfall Wood, just beneath the vegetable soil, Mr. Wetherell found one of those strange medleys which geologists were then wont to dismiss as "diluvium." Here, as far south as the Thames Valley, were waterworn fragments of granite, mountain limestone, coal, red chalk-indeed rock-specimens from all the northern formations, with a similarly heterogeneous collection of 
fossil remains. Agassiz had not as yet broached the great conception of the glacial period; the diluvium reigned supreme. Year by year more extensive patches of fossiliferous clays and gravels were found adjacent to Muswell Hill. From Finchley and Whetstone an abundance of fossils proper to the chalk and oolite formations was obtained, and whole hampers of belernnites were sent off to Prof. Phillips at Oxford for the purpose of his monograph on that genus. But the drift itsclf remained an isolated phenomenon. It was left to men of the younger generation to attack a problem as worthy of solution as the problems of Cambria and Siluria.

During the last five or six years, the Finchley and Muswell Hill drift has excited fresh attention. The Grcat Northern Branch Railway from East End to Finchley has exposed some fine sections, and a body of earnest field-geologists-the Geologists' Association-has been at hand to take advantage of the opportunities thus afforded. In the same period MIr. Wood has published his "Sequence of the Glacial Beds," and the Geological Survey a map of the superficial deposits of the district.

Lying on the hills and plateaux, the North London drifts have a scenic interest. They form noticeable features in the Middlesex Iandscapes, as may be seen in the accompanying geological map of the district (Fig. I). The valleys and streams around the plateaux delineate in an instructive manner the cxtent of the glacial beds, whilst they suggest the action of those meteorological forces which have reduced these beds to their present limits since their elevation above the sea.
But unlike the moraines of Snowdonia and other mountain districts, these much older lower ground accumulations are not, in the view of most English glacialists, the immediate cleposits of land ice. Contrary to the beliefs of the Scotch geologists, who would regard them as the equivalents of the Till, they are referred to the era of the great submergence of England beneath the glacial sea. They are the transported material of the submarine terminal moraine. As the ice-foot retired before the submerging sea, it left behind it the debris of the rocks it had degraded to be transported by bergs and rafts over the Middlesex of the future.

The glacial deposits at Finchley station, although they conform to the general character of such beds in the south-wcstern counties, have certain features which may prove to be more developed here than elsewhere, and may, at some future time, help to connect these deposits with their more local sources of supply. The preponderance of the characteristic Oxford clay fossil Gryptea dilatata is remarkable, and whilst the chalk and the Oxford clay arc the most largely represented, the formations of which the fewest traces are found are the gault and the London clay. Forcign blocks, transported by ice, are generally absent from the district. Blocks of Sarsen sandstone are not uncommon, but it is worthy of notice that they are only found in the drift.

The vast sources of supply for the flint pebbles which abound in the glacial gravels of the district are still represented in the small and local remainders which cap the high ground at Totteridge, and are found at Barnet,
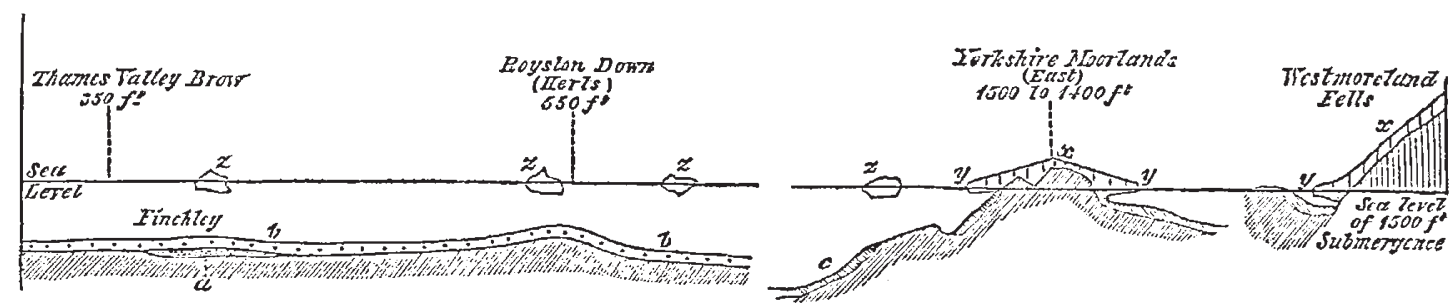

FIG 2.-Section showing the degree of submergence indicated by the upper Glacial Deposits. References-a, The Mliddle Glacial. b, The Chalky Boulder Clay. $c$, The Purple Clay without Chalk. $x$, The Ice Sheet. $y$, The Ice-foot. $z$, Floating Ice.

where these second-hand accumulations of the Lower or Middle Bagshot, disturbed or redeposited, are free from the quartzites of the glacial gravels, and exhibit an unmixed Eocene lineage.

After years of untold labour, which offer a noble example of private enterprise in the cause of geology, Mr. Searles V. Wood, jun., has established the succession of the glacial beds of the east of England and the central counties, which is here given in abstract :-

\section{Post-glacial Beds}

I. UPPER GLACIAL.-I. The purple boulder clay of Yorkshire without chalk. 2. The purple boulder clay with chalk. 3. The Great Chalky Boulder Clay of the Sonth of England (e.g. at Finchley and Muswell Hill).

II. MIIDde Glacial.-The Middle Glacial Sands and Pebbly Gravels of the South-East of England and the Central Counties (e.g., the Finchley and MIuswell Hill sands and pebbly gravels).

III. LOWER GLACIAL. - The Contorted Drift of Norfolk, the Cromer Till, and the Pebbly Sands of Norfolk and Suffolk (Upper Crag).

A few words further in explication of this sequence will show how wide an area of England is concerned in the deposits with which the Finchley drifts are thus correlated.

The deposit to which the Finchley chalk boulder clay belongs stretches in an intermittent way from the lower
Thames Valley to Central Lincolnshire, and from the Eastern Counties of Norfolk and Suffolk to East Staffordshire. The Finchley sands and gravels extend (mostly covered by the boulder clay) over nearly all the three large counties of Norfolk, Suffolk, and Essex, and are present in Herts, Bucks, and Leicester. So there is no insignificant number of geologists, away from the region of the old glaciers, who may study in their own locality the memorials of the great glacial period in England.

Inasmuch as the maps which Nature has laid down in the ground beneath us are historical as well as physical, this sequence introduces us to a series of consccutive events in the earlier history of the great Glacial Period. In the lower glacial the age of Ice begins. In the next deposit we notice a pause in the Arctic conditions which had prevailed. The formation of that characteristically glacial deposit, the boulder clay, was arrested, and the sands and gravels (middle glacial), of milder watcrs, took its place. Then the Arctic conditions returned, and brought in the chalky boulder clay. At length the higher rocks were brought within the reach of the sea, until the Yorkshire Wolds were submerged, and eventually the Westmoreland fells yielded their débris to be spread over the sea-bottom (Fig 2). That the glacial period should have left its memorials so far south in our island as the valley of the Thames, was a matter of incredulity among many geologists, even so recently as ten years since, when Sir Charles Lyell had compelled attention to the MIuswell Hill drift in the "Antiquity of Man." That the 
drift of the glacial period did not once extend over the counties south of the Thames has yet to be demonstrated, and those geologists who hold that we have already discovered the original southern limits of the glacial clays and gravels in England, have yet to explain the condition of these deposits of the north brow of the Thames Valley, where they are as pelagic in character as they are a hundred miles farther north.

The dwellers in the south of England have thus been compensated for their distance from the bolder region of the old British glaciers, of perched blocks, and terminal moraines. The glacial period has now been brought home, as it were, to their own doors. By the classification of the glacial beds which we now possess, patches of clay and gravel which seemed to have a sporadic and insignificant character are seen to belong to a great and historical series. In the presence of such "diluvium" as that of Muswell Hill, with its astonishing medley of organic remains, it needs no longer to be asked,-

"What seas receding from what former world

Consigned these tribes to stony sepulchres?"

We know now that it was an icy sea.

\section{HENRY IVALKER}

\section{FLIGHT NOT AN ACQUISITION}

$A$ FEW weeks ago, when at Ravenscroft (the residence of Lord Amberley), I shut up five unfledged swallows in a small box not much larger than the nest from which they were taken. The little box, which had a wire front, was hung on the wall near the nest, and the young swallows were fed by their parents through the wires. In this confinement, where they could not even extend their wings, they were kept until after they were fully fledged. I was not at Ravenscroft when the birds were liberated, but the following observations were made by Lord and Lady Amberley, who have kindly communicated them to me. On going to set the prisoners free, one was found dead-they were all alive on the previous day. The remaining four were allowed to escape one at a time. Two of these were perceptibly wavering and unsteady in their flight. One of them after a flight of about 90 yards disappeared among some trees; the other, which flew more steadily, made a sweeping circuit in the air after the manner of its kind, and alighted, or attempted to alight, on a branchless stump of a beech; at least it was no more seen. I give the unabridged account of No. 3 and of No. 4 as it stands in the notes made at the time by Lady Amberley. "No. 3 (which was seen on the wing for about half-a-minute), flew near the ground first round Wellingtonia, over to the other side of kitchen garden, past beehouse, back to the lawn, round again, and into a beech tree. No. 4 flew well near the ground, over a hedge twelve feet high to the kitchen garden, through an opening into the beeches, and was last seen close to the ground." "The following remarks were added subsequently: "The swallows never flew against anything, nor was there in their avoiding objects any appreciable difference between them and old birds. No. 3 swept round the Wellingtonia, and No. 4 rose over the hedge just as we see the old swallows doing cvery hour of the day." It remains to add that each of these birds was weighted with a small collar of coloured cloth, put on for the purpose of marking them; and that an old swallow on being set free encumbered by a similar adornment, exhibited the same unsteadiness in its flight.

There is little reed to make any remark on the above facts. In proving the flight of birds, and their power of guiding their course through the air in accordance with their sensations of sight, not to be an acquisition, they support the general doctrine that all of what may be called the professional knowledge and skill of the various species of animals come to them by intuition, and not as the results of their individual experiences. With wings there comes to the bird the power to use them. Why, then, should we believe that because the human infant is born without tceth, it should, when they do make their appearance, have to discover their use? The swallow, the first time it is in the air takes care, or rather does not need to take care, not to dash its brains out against a stone wall. Why, then, should we believe man to have no instinctive faculty of interpreting his visual sensations ?

DOUGLaS A. SPALDiNG

\section{BRITISH ARCHAEOLOGICAL INSTITUTE}

THE annual meeting of this Institute commenced at Exeter on Tuesday, July 29, the President for the year being the arl of Devon. Many valuable papers were read, and many interesting excursions made in the neighbourhood; the reception by the Mayor, the local authorities, and the inhabitants generally, has been most enthusiastic. The Congress was brought to a close on Tuesday last, and is declared to have been the most successful meeting of the kind ever held. Of the many valuable papers read we give the following by $\mathrm{Dr}$. E. A. Freeman, on "The Place of Exeter in English History."

He remarked that it sometimes came into the mind of an English traveller in other lands that the cities of his own country must seem of small account in the eyes of a traveller from the land which he visited. He spoke of course as an antiquary and not of modern prosperity and splendour. As a rule an English town did not make the same impression as an artistic and antiquarian object as did towns of Italy, Germany, Burgundy, France, or Aquitaine But whilst we had few cities as rich at once in history and art as many of those on the Continent, yet we need not grieve; for whatever was taken from particular districts was added to the general history of our country. Why was the history of Nuremburg greater than that of Exeter? Simply because the history of England was greater than that of Germany, The domestic history of an English town which had always been content to be a municipality, and had never aspired to be a sovereign commonwealth, seemed tame beside the stirring annals of the free cities of Italy and Germany. But for that especial reason it had a value of its own, it had not struggled for the greatness of its own, but it had done its work as part of a greater whole-it had played its part in building up a nation. And the comparison beween the lowly English munici. pality and the proud Italian or German commonwealth had also an interest of another kind. The difference between the two was simply the difference implied in the absence of political independence in the one case and its presence in the other. The difference was purely external - the internal constitution-history and revolutions-often presenting the most striking analogies. In both might often be seen the change from democracy to oligarchy, and from oligarchy to democracy. In both they might see men who, in old Greece, would have taken their places as demagogues, perhaps tyrants. Exeter had something to tell of Earl and Countess of Devon; Bristol of its halfcitizens, half tyrants, the Lords of Berkeley. In the free cities of the Continent we saw what English cities might have been if the royal power in England had been no stronger than that of the Emperors, and if England had therefore split up into separate states like Germany, Italy, and Gaul. In England the constant tendency had been to unity and to make every local power subordinate to that of the king, and it was this that had made the difference between a municipality like Exeter and a commonwealth like Florence. In Exeter reflections of this kind had a special fitness. No city in England had a history which came so near to that of the great conti- 